\title{
Allium Sativum (Garlic) Extract as Nontoxic Corrosion Inhibitor
}

\author{
K. Rajam, ${ }^{1}$ S. Rajendran, ${ }^{2,3}$ and R. Saranya ${ }^{4}$ \\ ${ }^{1}$ Department of Chemistry, K. L. N College of Information Technology, Pottapalayam 630 611, India \\ ${ }^{2}$ PG and Research Department of Chemistry, GTN Arts College, Dindigul 624 005, India \\ ${ }^{3}$ R.V.S. School of Engineering and Technology, Dindigul 624005, India \\ ${ }^{4}$ Department of Chemistry, Jayalakshmi Institute of Technology, Thoppur, Tamilnadu 636352, India \\ Correspondence should be addressed to K. Rajam; rajam98@yahoo.co.in
}

Received 13 March 2012; Revised 21 May 2012; Accepted 1 June 2012

Academic Editor: Deniz Ekinci

Copyright ( 2013 K. Rajam et al. This is an open access article distributed under the Creative Commons Attribution License, which permits unrestricted use, distribution, and reproduction in any medium, provided the original work is properly cited.

The inhibition efficiency (IE) of an aqueous extract of garlic in controlling corrosion of carbon steel in well water in the absence and presence of $\mathrm{Zn}^{2+}$ has been evaluated by mass-loss method. The formulation consisting of $2 \mathrm{~mL}$ of garlic extract and $25 \mathrm{ppm} \mathrm{Zn}{ }^{2+}$ offers $70 \%$ inhibition efficiency to carbon steel immersed in well water. Polarization study reveals that this formulation controls the anodic reaction predominantly. FTIR spectra reveal that the protective film consists of $\mathrm{Fe}^{2+}$-allicin complex and $\mathrm{Zn}(\mathrm{OH})_{2}$.

\section{Introduction}

Environmental friendly inhibitors have attracted several researchers. Natural products are nontoxic, biodegradable, and readily available. They have been used widely as inhibitors. Natural products such as caffeine $[1,2]$ have been used as inhibitors. Corrosion inhibition of steel by plant extracts in acidic media has been reported $[3,4]$. Scale inhibiting nature of plant extracts for various kinds of metals are summarized briefly [5]. Aqueous extract of Rosemary leaves [6], Zanthoxylum alatum [7], and Lawsonia [8] have been used to inhibit corrosion of metals. Corrosion inhibition of iron in hydrochloric acid solutions by naturally occurring henna has been investigated [9]. Corrosion inhibition of carbon steel in low chloride media by an aqueous extract of Hibiscus rosasinensis Linn has been evaluated [10]. Corrosion inhibition investigation of natural inhibitors is particularly interesting because they are nonexpensive, ecologically friendly, and possess no threat to the environment. The present work is undertaken:

(i) to evaluate the inhibition efficiency (IE) of an aqueous extract of garlic in controlling the corrosion of carbon steel in well water in the absence and presence of $\mathrm{Zn}^{2+}$

(ii) to analyze the protective film formed on the carbon steel by FTIR spectra, (iii) to understand the mechanistic aspects of corrosion inhibition by potentiodynamic polarization study,

(iv) and to propose a suitable mechanism for corrosion inhibition.

\section{Experimental Procedure}

2.1. Preparation of Garlic Extract. An aqueous extract of garlic was prepared by grinding $20 \mathrm{~g}$ of garlic with double distilled water, filtering the impurities, and making up to $100 \mathrm{~mL}$. The extract was used as corrosion inhibitor in the present study.

2.2. Preparation of Specimens. Carbon steel specimens $(0.0267 \% \mathrm{~S}, 0.06 \% \mathrm{P}, 0.4 \% \mathrm{Mn}, 0.1 \% \mathrm{C}$, and the rest iron) of dimensions $1.0 \mathrm{~cm} \times 4.0 \mathrm{~cm} \times 0.2 \mathrm{~cm}$ were polished to a mirror finish and degreased with trichloroethylene.

2.3. Mass-Loss Method. Relevant data on the well water used in this study are given in Table 1. Carbon steel specimens in triplicate were immersed in $100 \mathrm{~mL}$ of well water containing various concentrations of the inhibitor in the presence and absence of $\mathrm{Zn}^{2+}$ for 3 days. The weight of the specimens before and after immersion was determined using Shimadzu balance, model AY 62. The corrosion products were cleansed 
TABLE 1: Parameters of well water.

\begin{tabular}{lc}
\hline Parameter & Value \\
\hline $\mathrm{pH}$ & 8.6 \\
Conductivity & $2620 \mu \mathrm{mho} / \mathrm{cm}$ \\
TDS & $1835 \mathrm{mg} / \mathrm{L}$ \\
Chloride & 450 \\
Sulphate & 110 \\
Total hardness & 96 \\
\hline
\end{tabular}

TABLE 2: Corrosion rate (CR) of carbon steel immersed in well water in the absence and presence of inhibitors and the inhibition efficiency (IE) obtained by mass-loss method. Immersion period: 3 days; inhibitor: garlic extract $+\mathrm{Zn}^{2+}$.

\begin{tabular}{lcccc}
\hline & \multicolumn{4}{c}{$\mathrm{Zn}^{2+}$} \\
Garlic extract $\mathrm{mL}$ & $0(\mathrm{ppm})$ & $25(\mathrm{ppm})$ \\
& CR (mdd) & IE \% & CR (mdd) & IE \% \\
\hline 0 & 22.42 & - & 17.94 & 20 \\
2 & 11.21 & 50 & 6.73 & 70 \\
4 & 7.17 & 68 & 4.48 & 80 \\
6 & 2.24 & 90 & 1.79 & 92 \\
8 & 1.35 & 94 & 0.90 & 96 \\
\hline
\end{tabular}

efficiencies are also given in the Table. It is seen from Table 2 that the aqueous extract of garlic is a good inhibitor to carbon steel in well water. $2 \mathrm{~mL}$ of garlic shows $50 \%$ IE. As concentration of garlic extract increases, IE also increases. That is, at higher concentrations, garlic accelerates corrosion inhibition $[12,13]$.

SCHEME 1: Structure of allicin.

with Clarke's solution [11]. The inhibition efficiency (IE) was then calculated using the following equation:

$$
\mathrm{IE}=100\left[1-\left(\frac{W_{2}}{W_{1}}\right)\right] \%,
$$

where $W_{1}$ is the corrosion rate in the absence of the inhibitor, and $W_{2}$ is the corrosion rate in the presence of the inhibitor.

2.4. Surface Examination. The carbon steel specimens were immersed in various test solutions for a period of 3 days, taken out and dried. The nature of the film formed on the surface of metal specimens was analyzed by FTIR spectroscopic study.

2.5. Potentiodynamic Polarization. Polarization studies were carried out in an $\mathrm{H} \& \mathrm{CH}$ electrochemical work station impedance analyzer model CHI 660A. A three-electrode cell assembly was used. The working electrode was carbon steel. A saturated calomel electrode (SCE) was used as the reference electrode, and a rectangular platinum foil was used as the counter electrode.

2.6. FTIR Spectra. FTIR spectra were recorded in a PerkinElmer 1600 spectrophotometer. The film was carefully removed, mixed thoroughly with $\mathrm{KBr}$, made into pellets, and FTIR spectra were recorded.

\section{Results and Discussion}

3.1. Analysis of Results of Mass-Loss Method. The corrosion rate (CR) of carbon steel immersed in well water (whose composition is given in Table 1) in the absence and presence of inhibitor systems is given in Table 2. The inhibition

3.1.1. Influence of $\mathrm{Zn}^{2+}$ on the Inhibition Efficiency of Garlic Extract. The influence of $\mathrm{Zn}^{2+}$ on the IE of garlic extract is given in Table 2. In the presence of $\mathrm{Zn}^{2+}$ (25 ppm), excellent inhibitive property is shown by garlic extract. For example, $2 \mathrm{~mL}$ of garlic extract accelerate corrosion of carbon steel $(\mathrm{IE}=50 \%) ; 25 \mathrm{ppm}$ of $\mathrm{Zn}^{2+}$ have $20 \% \mathrm{IE}$, but their combination has $70 \%$.

3.2. Analysis of Polarization Curves. The potentiodynamic polarization curves of carbon steel immersed in well water in the absence and presence of inhibitors are shown in Figures 1(a) and 1(b). The corrosion parameters are given in Table 3. When carbon steel is immersed in well water the corrosion potential is $-704 \mathrm{mV}$ versus SCE (saturated calomel electrode). The corrosion current is $2.600 \times 10^{-6} \mathrm{~A} / \mathrm{cm}^{2}$. When $2 \mathrm{~mL}$ of garlic extract and $25 \mathrm{ppm}$ of $\mathrm{Zn}^{2+}$ are added to the above system, the corrosion potential shifted to the anodic side $(-690 \mathrm{mV}$ versus SCE). This suggests that this formulation controls the anodic reaction predominantly. In the presence of the inhibitor system, the corrosion current decreases from $2.600 \times 10^{-6} \mathrm{~A} / \mathrm{cm}^{2}$ to $2.353 \times 10^{-6} \mathrm{~A} / \mathrm{cm}^{2}$. This suggests the inhibitive nature of this inhibitor system $[14,15]$.

3.3. Analysis of FTIR Spectra. The active principle in an aqueous extract of garlic is allicin. It consists of $\mathrm{S}=\mathrm{O}$ and $\mathrm{S}$ group.

A few drops of an aqueous extract of garlic were dried on a glass plate. A solid mass was obtained. Its FTIR spectrum is shown Figure 2(a). Vinyl group appeared at $1026.28 \mathrm{~cm}^{-1}$. S $=\mathrm{O}$ appeared at $1026 \mathrm{~cm}^{-1}$ and $\mathrm{S}$ at $1237.58 \mathrm{~cm}^{-1}$. Thus the structure of allicin is confirmed by FTIR spectra (Scheme 1) [16]. The FTIR spectrum of complex prepared by mixing garlic extract and $\mathrm{Zn}^{2+}$ is shown in Figure 2(b). The band due to conjugated double bonds shifts from 
TABLE 3: Corrosion parameters of carbon steel immersed in well water in the absence and presence of inhibitors. Inhibitor system: garlic extract $+\mathrm{Zn}^{2+}$ system

\begin{tabular}{lcccc}
\hline System & $\begin{array}{c}E_{\text {corr }} \\
\mathrm{mV} \text { versus SCE }\end{array}$ & $\begin{array}{c}b_{a} \\
(\mathrm{mV} / \text { decade })\end{array}$ & $\begin{array}{c}b_{c} \\
(\mathrm{mV} / \text { decade })\end{array}$ & $\begin{array}{c}I_{\text {corr }} \\
\left(\mathrm{A} / \mathrm{cm}^{2}\right)\end{array}$ \\
\hline Well water & -704 & 229.7 & 177.7 & $2.600 \times 10^{-6}$ \\
Garlic extract $(2 \mathrm{~mL})+\mathrm{Zn}^{2+}(25 \mathrm{ppm})$ & -690 & 220.5 & 179.1 & $2.353 \times 10^{-6}$ \\
\hline
\end{tabular}

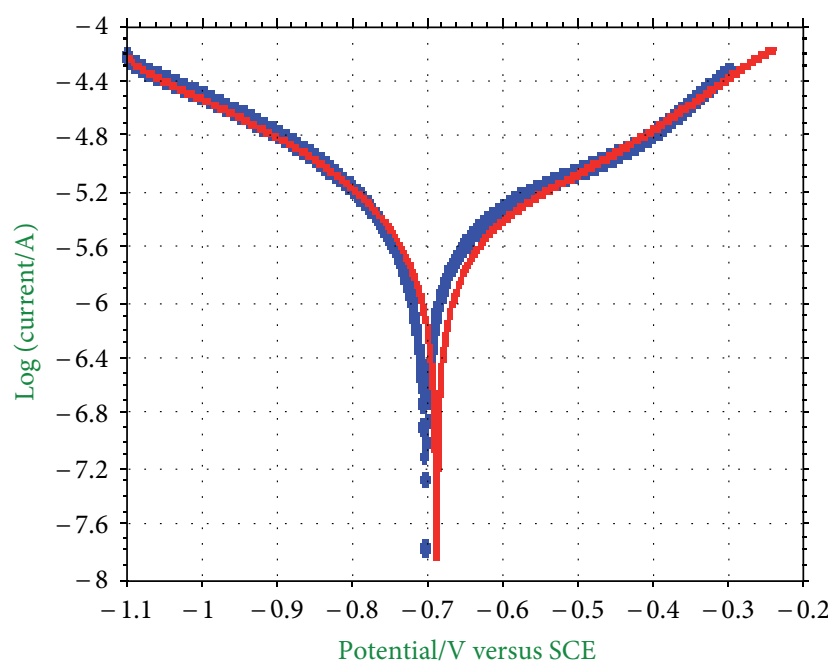

FIGURE 1: Polarization curves of carbon steel immersed in (a) well water and (b) well water $+2 \mathrm{~mL}$ garlic extract $+25 \mathrm{ppm}$ of $\mathrm{Zn}^{2+}$.

$3757.23 \mathrm{~cm}^{-1}$ to $3819.62 \mathrm{~cm}^{-1}$. The band at 608.46 corresponds to $\mathrm{Zn}-\mathrm{O}$ stretching. The $\mathrm{OH}$ stretching frequency appears at $3407.06 \mathrm{~cm}^{-1}$. This confirms the formation of $\mathrm{Zn}(\mathrm{OH})_{2}$ on the cathodic sites of the metal surface [1719]. Since there is complete coordination between $\mathrm{Fe}^{2+}$ and allicin, the band due to the formation of the complex gets vanished in the FTIR spectrum of the film formed on the surface of carbon steel by garlic extract (Figure 2(b)) [20,21].

3.4. Mechanism of Corrosion Inhibition. Mass-loss study reveals that the formulation consisting of $2 \mathrm{~mL}$ of garlic extract $+25 \mathrm{ppm}$ of $\mathrm{Zn}^{2+}$ offers $70 \%$ IE to carbon steel immersed in well water. Polarization study reveals that this formulation controls the anodic reaction predominantly. FTIR spectra reveal that the protective film consists of $\mathrm{Fe}^{2+}$ allicin complex and $\mathrm{Zn}(\mathrm{OH})_{2}$. In order to explain the above facts in a holistic way, the following mechanism of corrosion inhibition is proposed.

(i) When the formulation consisting of well water, garlic extract, and $\mathrm{Zn}^{2+}$ is prepared, there is formation of $\mathrm{Zn}^{2+}$-allicin complex in solution.

(ii) When carbon steel is immersed in the solution, the $\mathrm{Zn}^{2+}$-allicin complex diffuses from the bulk of the solution towards the metal surface.

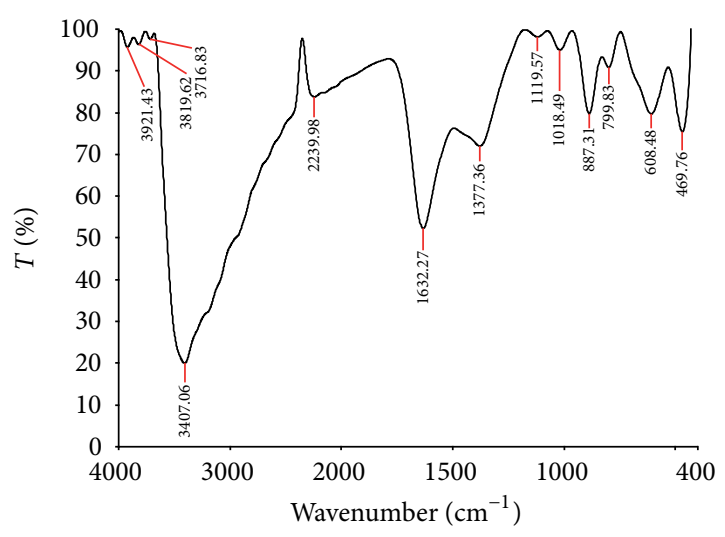

(a)

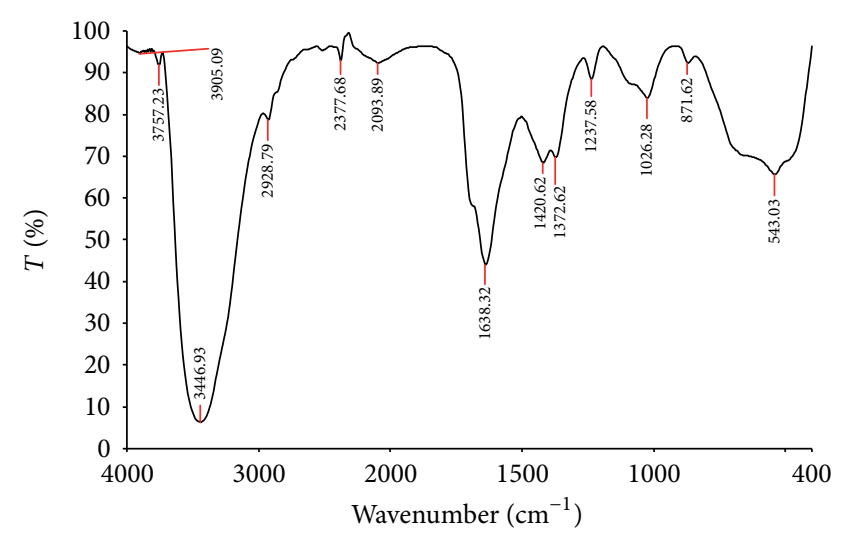

(b)

FIGURE 2: (a) FTIR spectra of solid mass obtained by evaporating the garlic extract. (b) FTIR spectra of film formed on surface of the carbon steel specimen after immersion in well water containing $2 \mathrm{~mL}$ of garlic extract and $25 \mathrm{ppm}$ of $\mathrm{Zn}^{2+}$.

(iii) On the metal surface, $\mathrm{Zn}^{2+}$-allicin complex is converted into $\mathrm{Fe}^{2+}$-allicin complex. $\mathrm{Zn}^{2+}$ is released.

(iv) $\mathrm{Zn}^{2+}$-allicin $+\mathrm{Fe}^{2+} \rightarrow \mathrm{Fe}^{2+}$-allicin $+\mathrm{Zn}^{2+}$.

(v) The released $\mathrm{Zn}^{2+}$ combines with $\mathrm{OH}^{-}$to form $\mathrm{Zn}(\mathrm{OH})_{2}$.

(vi) $\mathrm{Zn}^{2+}+2 \mathrm{OH}^{-} \rightarrow \mathrm{Zn}(\mathrm{OH})_{2}$.

(vii) Thus, the protective film consists of $\mathrm{Fe}^{2+}$-allicin complex and $\mathrm{Zn}(\mathrm{OH})_{2}$. 


\section{Conclusions}

The present study leads to the following conclusions:

(i) the formulation consisting of $2 \mathrm{~mL}$ garlic extract and $25 \mathrm{ppm}$ of $\mathrm{Zn}^{2+}$ offers $70 \%$ inhibition efficiency to carbon steel immersed in well water;

(ii) polarization study reveals that this formulation controls the anodic reaction predominantly;

(iii) FTIR spectra reveal that the protective film consists of $\mathrm{Fe}^{2+}$-allicin complex and $\mathrm{Zn}(\mathrm{OH})_{2}$.

\section{Acknowledgments}

Authors are thankful to their managements and University Grants Commission, India, for the help and encouragement.

\section{References}

[1] S. Rajendran, S. Vaibhavi, N. Anthony, and D. C. Trivedi, "Transport of inhibitors and corrosion inhibition efficiency," Corrosion, vol. 59, no. 6, pp. 529-534, 2003.

[2] S. Rajendran, A. J. Amalraj, M. J. Joice, N. Anthony, D. C. Trivedi, and M. Sundaravadivelu, "Corrosion inhibition by the caffeine $-\mathrm{Zn}^{2+}$ system," Corrosion Reviews, vol. 22, no. 3, pp. 233-248, 2004.

[3] L. R. Chauhan and G. Gunesekaran, "Corrosioninhibition of mildsteel by plantextract in dilute $\mathrm{HCl}$ medium," Corrosion Science, vol. 49, pp. 1143-1161, 2007.

[4] A. M. Abdel-Gaber, B. A. Abd-El-Nabey, I. M. Sidahmed, A. M. El-Zayady, and M. Saadawy, "Inhibitive action of some plant extracts on the corrosion of steel in acidic media," Corrosion Science, vol. 48, no. 9, pp. 2765-2779, 2006.

[5] S. Rajendran, V. G. Sri, J. ArockiaSelvi, and A. J. Amalraj, "Corrosion inhibition by plant extracts-an overview," Bulletin of Electrochemistry, vol. 21, pp. 367-377, 2005.

[6] M. Kliskic, J. Radoservic, S. Gudic, and V. Katalinic, "Aqueous extract of Rosmarinus officinalis L. as inhibitor of Al-Mg alloy corrosion in chloride solution," Journal of Applied Electrochemistry, vol. 30, no. 7, pp. 823-830, 2000.

[7] G. Gunasekaran and L. R. Chauhan, "Eco friendly inhibitor for corrosion inhibition of mild steel in phosphoric acid medium," Electrochimica Acta, vol. 49, no. 25, pp. 4387-4395, 2004.

[8] A. Y. El-Etre, M. Abdallah, and Z. E. El-Tantawy, "Corrosion inhibition of some metals using lawsonia extract," Corrosion Science, vol. 47, no. 2, pp. 385-395, 2005.

[9] A. Chetouani and B. Hammouti, "Corrosion inhibition of iron in hydrochloric acid solutions by naturally henna," Bulletin of Electrochemistry, vol. 19, no. 1, pp. 23-25, 2003.

[10] K. Anuradha, R. Vimala, B. Narayanasamy, J. A. Selvi, and S. Rajendran, "Corrosion inhibition of carbon steel in low chloride media by an aqueous extract of Hibiscus rosa-sinensis Linn," Chemical Engineering Communications, vol. 195, no. 3, pp. 352-366, 2008.

[11] G. Wranglan, Introduction to Corrosion and Protection of Metals, Chapman and Hall, London, UK, 1985.

[12] V. S. Shastri, Corrosion Inhibitors- Principles and Applications, John Wiley \& Sons, 1998.

[13] M. A. Pech-Canul and P. Bartolo-Pérez, "Inhibition effects of Nphosphono-methyl-glycine $/ \mathrm{Zn}^{2+}$ mixtures on corrosion of steel in neutral chloride solutions," Surface and Coatings Technology, vol. 184, no. 2-3, pp. 133-140, 2004.

[14] S. Rajendran, P. Sumithra, B. S. Devi, and J. Jeyasundari, "Corrosion inhibition by spirulina," Zastita Materijala, vol. 50, broj 4, pp. 223-226, 2009.

[15] J. A. Selvi, S. Rajendran, V. G. Sri, A. J. Amalraj, and B. Narayanasamy, "Corrosion inhibition by beet root extract," Portugaliae Electrochimica Acta, vol. 27, no. 1, pp. 1-11, 2009.

[16] S. Rajendran, B. V. Apparao, and N. Palaniswamy, "Synergistic and biocidal effects of HEDP- $\mathrm{Zn}^{2+}$ - CTAB system on the inhibition of corrosion of mild steel in neutral aqueous environment," Bulletin of Electrochemistry, vol. 13, no. 12, pp. 441-447, 1997.

[17] V. C. Farmer, The Infrared Spectra of Minerals, Mineralogical Society, 1974.

[18] D. B. Powell and A. Woollins, "Vibrational spectra of metal, formamide complexes," Spectrochimica Acta A, vol. 41, no. 9, pp. 1023-1033, 1985.

[19] R. M. Silverstein, G. C. Bassler, and T. C. Morrill, Spectrometric Identification of Organic Compounds, John Wiley \& Sons, New York, NY, USA, 1986.

[20] S. Rajendran, M. K. Devi, A. P. P. Regis, A. J. Amalraj, J. Jeyasundari, and M. Manivannan, "Electroplating using environmental friendly garlic extract: a case study," Zastita Materijala, vol. 50, broj 3, pp. 131-140, 2009.

[21] B. S. Devi and S. Rajendran, "Influence of garlic extract on the inhibition efficiency oftrisodium citrate- $\mathrm{Zn}^{2+}$ system," International Journal of Chemical science and Technology, vol. 1, pp. 79-87, 2011. 

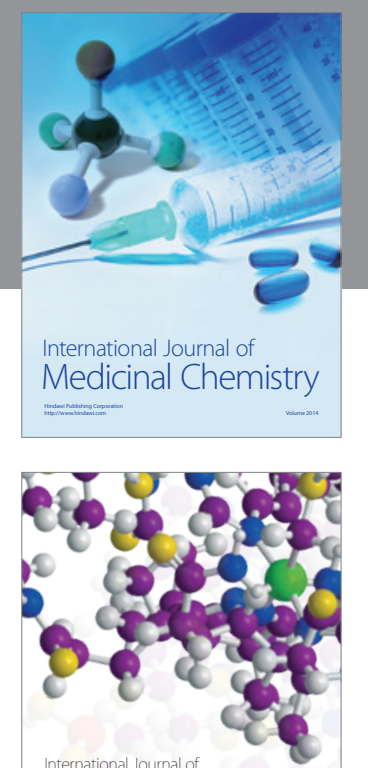

\section{Carbohydrate} Chemistry

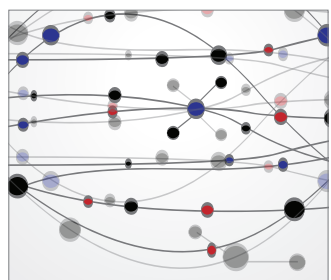

The Scientific World Journal
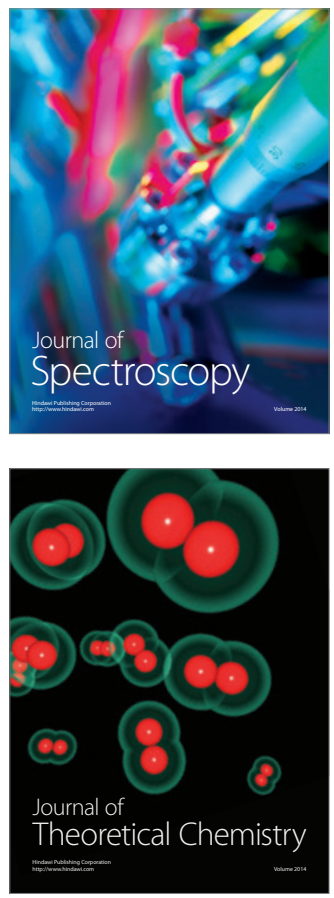
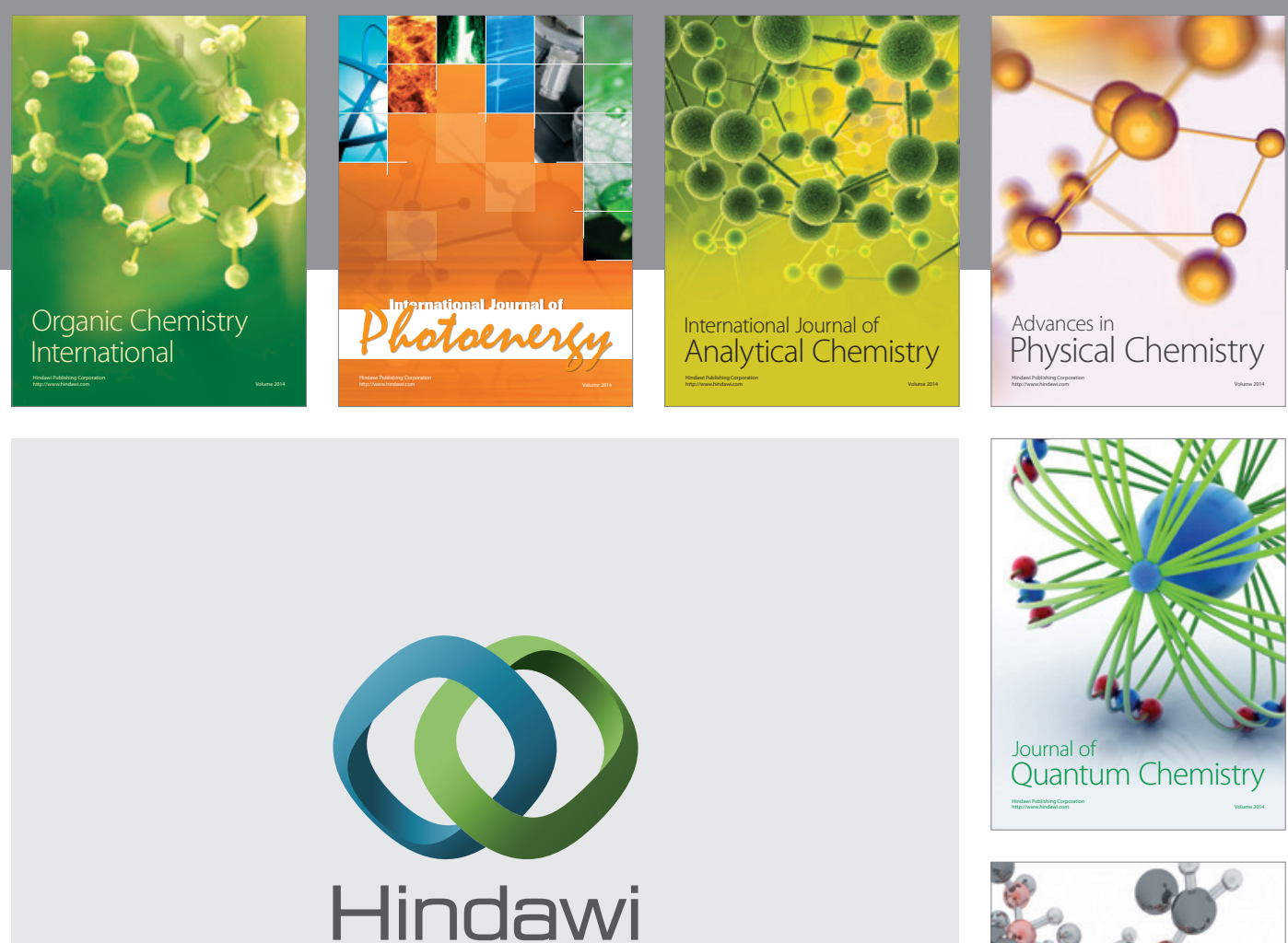

Submit your manuscripts at

http://www.hindawi.com

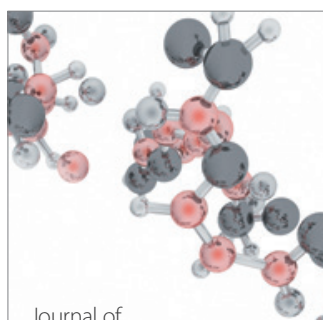

Analytical Methods

in Chemistry

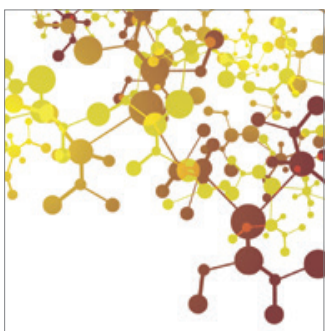

Journal of

Applied Chemistry

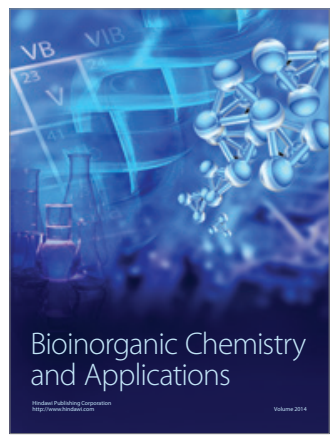

Inorganic Chemistry
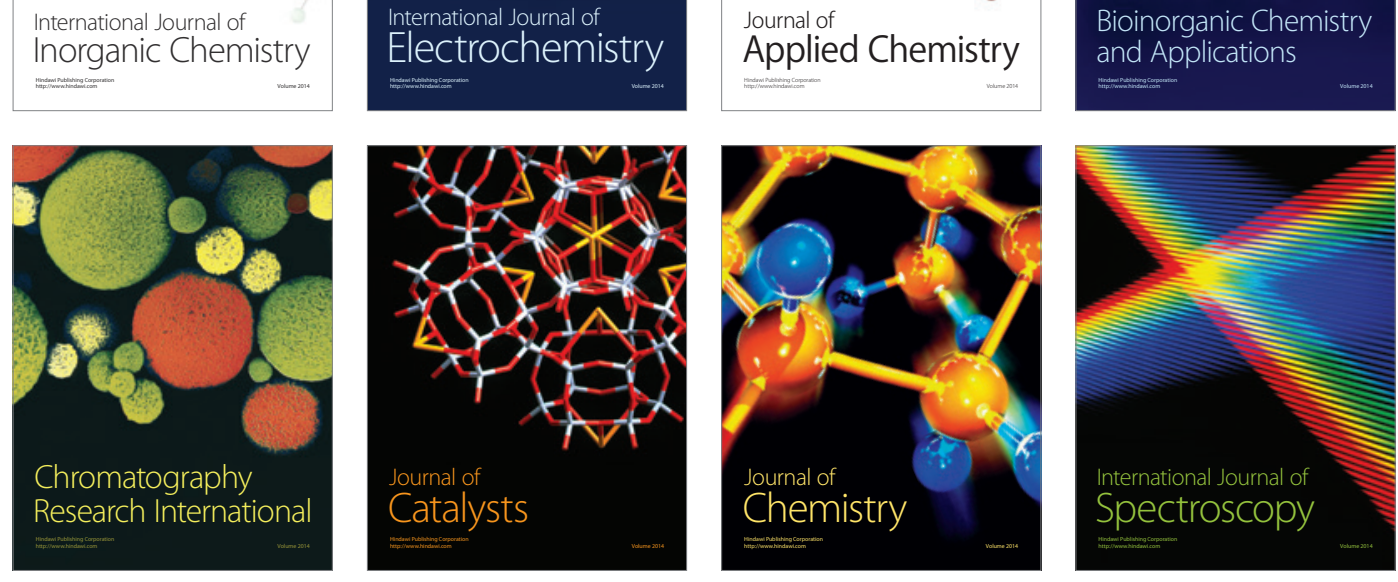